ADALAH : Buletin Hukum \&

Keadilan

Buletin Hukum \& Keadilan

@adalahuinjkt

\title{
Pencabutan Hak Politik Terhadap Terpidana Korupsi
}

Korupsi merupakan perilaku yang menyimpang dari norma-norma yang diterima dan dianut masyarakat, yang tujuannya untuk mendapatkan keuntungan pribadi. Perbuatan tindak pidana korupsi merupakan pelanggaran terhadap hak-hak sosial dan hak-hak ekonomi masyarakat, sehingga tindak pidana korupsi tidak dapat lagi digolongkan sebagai kejahatan biasa (ordinarycrimes) melainkan telah menjadi kejahatan luar biasa (extraordinanrycrimes). Sehingga dalam upaya pemberantasannya tidak lagi dapat dilakukan "secara biasa", tetapi dibutuhkan "cara-cara yang luar biasa" (extra-ordinarycrimes) (Maryanto, 2012).

Kejahatan

korupsi merupakan kejahatan bak musuh bangsa yang harus dilawan. Adapun tipe korupsi yang marak terjadi adalah korupsi yang kerap dilakukan oleh pejabat publik, seperti kepala daerah, DPR, DPRD, dan lain sebagainya. Dengan maraknya kasus korupsi yang tidak dapat dihindari menimbulkan permasalahan yang kompleks, bukan hanya dari sisi keuangan negara, akan tetapi korupsi telah membuat PR bagi pemerintah lembaga legislasi untuk terus meninjau kembali peraturan tentang penerapan hukuman yang telah dibuat dan diberlakukan.

Penetapan status terpidana terhadap pejabat publik dengan

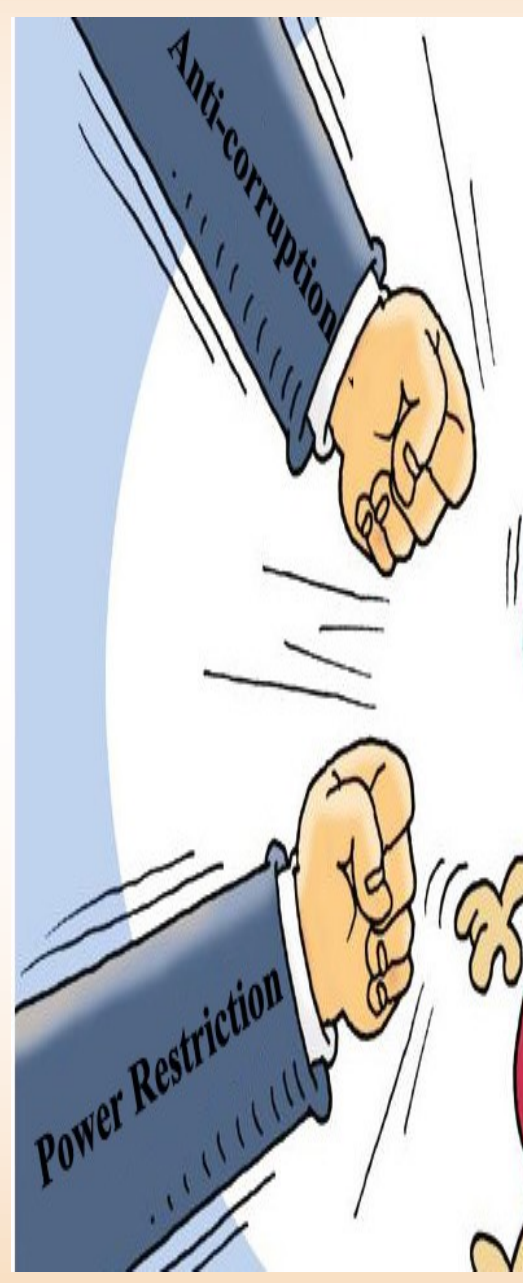

dalih korupsi merupakan fenomena yang memprihatinkan, pasalnya pejabat publik sebagai pelayan rakyat kini telah berkhianat, dengan menyalahgunakan wewenangnya untuk melakukan perbuatan yang tidak sepatutnya dilakukan. Pejabat publik yang tertangkap oleh lembaga anti riswah (KPK) merupakan buah dari kerja keras lembaga KPK guna menengakkan

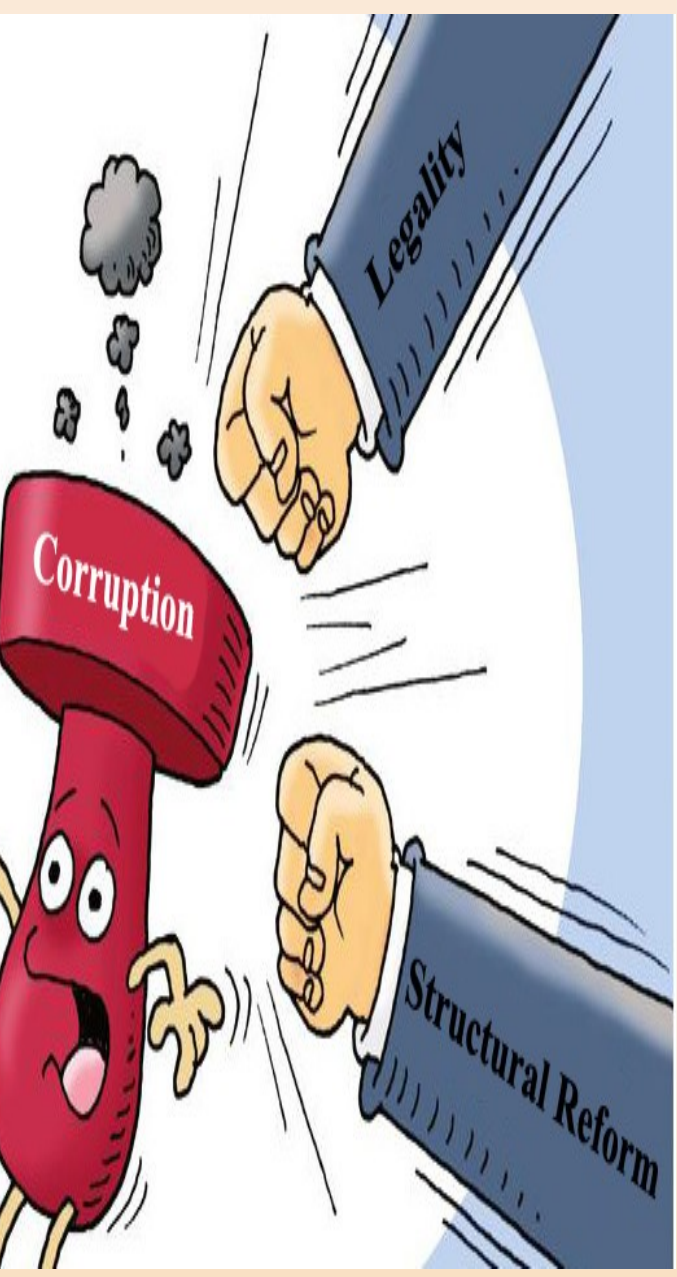

keadilan bagi seluruh masyarakat (Fathudin, 2015: 116).

Berdasarkan

laporan tahunan yang dilansir oleh KPK, jumlah pelaku korupsi yang berasal dari kalangan pejabat publik yang berasal dari DPR dan DPRD berkisar 32\% dari tahun 2004-2016 (Laporan KPK, 2016: 43). Dari data tersebut dapat dilihat bahwa tidak sedikit elit politik yang terjerat kasus korupsi. Hal ini tentu 
memilukan publik, akan tetapi Indonesia sebagai negara hukum terus berupaya untuk menyempurnakan hukum untuk memberantas korupsi khususnya di kalangan pejabat publik. Salah satu caranya adalah dengan memberikan hukuman tambahan terhadap terpidana korupsi.

Hukum pidana Indonesia telah memberikan dasar yuridis untuk melakukan pencabutan hak tertentu sebagai bentuk pidana tambahan. Pencabutan hak tertentu berupa hak menduduki jabatan publik, merupakan hukuman tambahan yang diharapkan memberikan perlindungan kepada masyarakat dari perilaku pejabat yang menyimpang.

Oleh karena itu pemerintah membuat suatu hak memilih dan dipilih melalui jabatan Non electoral official. Pencabutan hak politik diterapkan, jika sudah adanya putusan hakim yang inkrah. Pencabutan hak politik merupakan bentuk proteksi negara terhadap bangsa demi tercipta masyarakat yang good and clean governance, yang terbebas dari korupsi, kolusi dan nepotisme.

Sudah saatnya pemerintah menjaga marwah demokrasi dengan mengefektifkan hukum yang telah dibuat oleh lembaga legislasi. Karenanya, patutlah dalam hal ini Soekarno berkata dalam risalah sidang BPUPKI bahwa: "Perjuanganku lebih mudah karena mengusir penjajah, perjuanganmu akan lebih sulit karena melawan bangsamu sendiri."

aturan terhadap koruptor. Dalam KUHP dan redaksi pasalpasal dalam Undang-Undang Nomor 31 Tahun 1999 sebagaimana telah diubah dan ditambah dengan UndangUndang Nomor 20 tahun 2001 (selanjutnya disebut undangundang PTPK). Selain pidana pokok juga diatur mengenai pidana tambahan meliputi pencabutan hak-hak tertentu, perampasan barang bukti dan pengumuman putusan hakim. Pidana tambahan dalam KUHP diperluas pengertiannya menurut pasal 18 Undang-

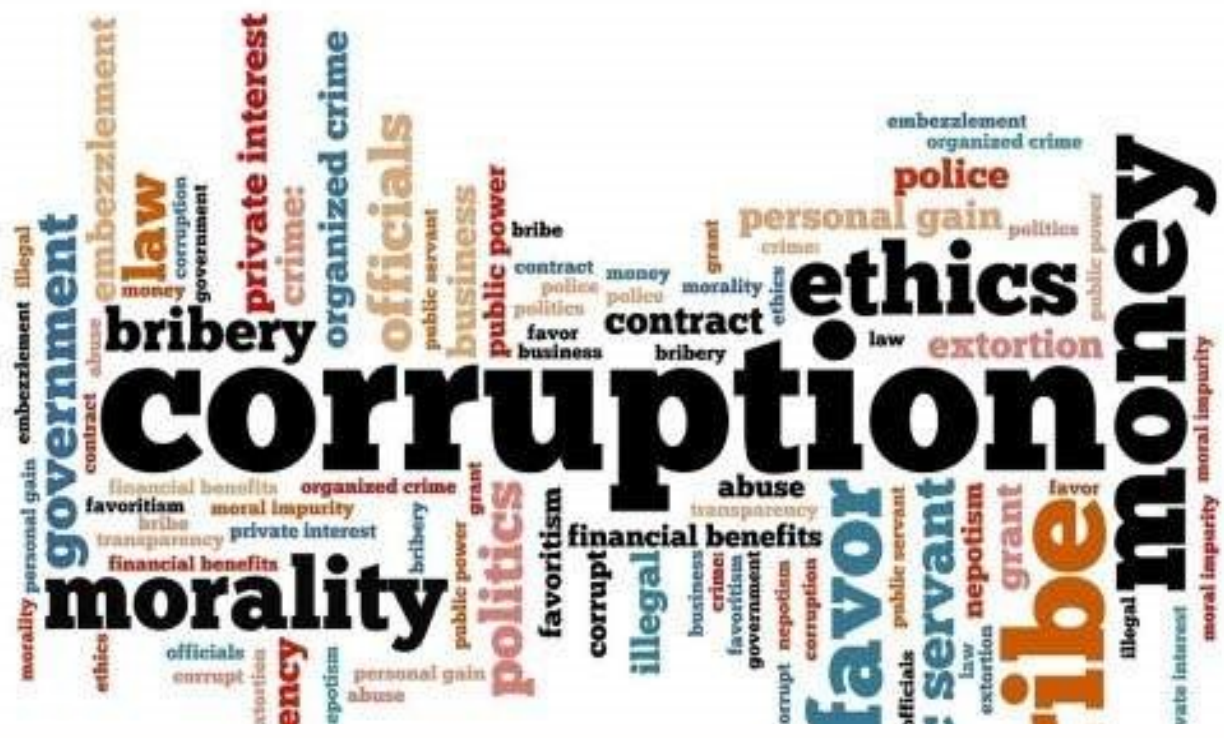
Undang PTPK meliputi perampasan benda bergerak dan atau tidak bergerak, pembayaran uang pengganti, penutupan usaha, dan pencabutan seluruh atau sebagian hak-hak tertentu.

Wakil Ketua Komisi Pemberantasan Korupsi Bambang Widjojanto menegaskan, KPK memang baru pertama kali menerapkan pidana tambahan berupa pencabutan hak politik bagi terdakwa kasus korupsi. Hal ini dimaksudkan untuk mengantisipasi koruptor yang masih ingin menjadi pejabat publik, seperti anggota DPR (www.kpk.go.id). Adapun Pencabutan hak politik, telah diterapkan kepada beberapa pejabat yang terjerat kasus korupsi, diantaranya; hakim Syarifuddin, Jaksa Urip Tri Gunawan, Irjen Djoko Susilo, Luthfi Hasan Ishaq, Rachmat Yasin, Irman Gusman, dan masih banyak lainnya.

Pencabutan hak politik merupakan pencabutan

\section{Pustaka Acuan:}

*Penulis adalah anggota Moot Court Community (MCC) FSH UIN Syarif Hidayatullah Jakarta dan anggota Perhimpunan Mahasiswa Hukum Indonesia (PERMAHI).

Fathudin, "Tindak Pidana Korupsi (Dugaan Penyalahgunaan Wewenang) Pejabat Publik (Perspektif Undang-Undang Nomor 30 Tahun 2014 Tentang Administrasi Pemerintahan)." Jurnal Cita Hukum 3, no. 1 (2015).

https://www.kpk.go.id/id/berita/berita-sub/1292-

pencabutan-hak-politik-terdakwa- diunduh pada 15 Juli 2017 09.07 Wib

Maryanto. 2012. "Pemberantasan Korupsi sebagai Upaya

Penegakan Hukum," dalam The Journal Computer, Volume 2, Nomor 2.

Laporan Komisi Pemberantasan Korupsi Tahun 2016.

'Adalah; Buletin Hukum dan Keadilan merupakan berkala ilmiah yang diterbitkan oleh Pusat Studi Konstitusi dan Legislasi Nasional (POSKO-LEGNAS), Fakultas Syariah dan Hukum UIN Syarif Hidayatullah Jakarta.

Penasehat: Prof. Dr. H. Abdul Ghani Abdullah, SH., Prof. Dr. H. A Salman Maggalatung, SH., MH. Pemimpin Redaktur: Indra Rahmatullah, Tim Redaktur: Nur Rohim Yunus, Fathuddin, Mara Sutan Rambe, Muhammad Ishar Helmi, Erwin Hikmatiar. Penyunting: Indah Furba, Hasin Abdullah. Setting \& Layout: Siti Anisaul Kamilah. 